\title{
/技/墭/報/告/
}

\section{ポリテトラフルオロエチレンの プレス延伸法による二軸延伸成形}

片岡 紘*1 ・松 澤 欽 哉*2 鋤 柄 正 幸*3 ・豊内 薰*1

\section{1. 緒言}

ポリテトラフルオロエチレン (以後 PTFE と略称す る) は, 耐熱性, 耐薬品性, 電気絶縁性, 低摩擦性な どにさまざまな卓越した特性をもち，広範な分野で指 定席を有する工業材料として利用されている. PTFE は分子鎖が伸び切った形をしており，そのため成形品 性能を発揮させるには分子量が $10^{6} \sim 10^{7}$ のオーダー の超高分子量重合体（以後 UHMW 重合体と略称す る)が一般に使用されている。このためこの PTFE は 融点を越えても極めて高い溶融粘度を有しており, 通 常の延伸加工は困難である.

この UHMW-PTFE の延伸シートについては, 引 張延伸法で成形された多孔質フィルム, ロール圧延法 で成形された一軸延伸テープなどが一般に知られ，工 業的に生産されている. UHMW-PTFE 生テープを引 張延伸すると微多孔>ィルムが得られ市,2) 「ゴアテッ クス」の商品名で広く知られている ${ }^{3)}$. PTFE 成形体を 一軸超延伸すると, 力学的に優れた物体が得られる ことが, 奥山などにより報告されている4) 6).これらの 報告はあるが，緻密な二軸延伸シートに関する報告は ない.

本研究ではわれわれがすでに報告したプレス延伸 法7を用いて UHMW-PTFE を二軸延伸し，緻密な特 徵ある二軸延伸シートを得たので報告する。

\section{2. 実験方法}

\section{1 実験に用いた各種材料}

a. 延伸するPTFE 厚肉原板 (PTFE-Preform と

\footnotetext{
${ }^{* 1}$ Kataoka, Hiroshi/Toyouchi, Kaoru 旭化成工業(侏) 樹脂技術センター 川崎市川崎区夜光 1-3-1（广 210）

*2 Matsuzawa, Kinya 旭化成アジア(㧣) 6 Battery Road, \#13-01, Singapore, 049909

*3 Sukigara, Masayuki 旭化成工業(侏) 鈴鹿工場 鈴鹿市平田中町 1-1（T 513） 1997.2.25 受理
}

略称）

日本バルカー (株)製, バルフロン\#7000, 比重 2.16 b. ガラス繊維配合 PTFEフィルム

日本バルカー (株)製, バルフロン切削テープ\#79002 NO (ガラス繊維 20 重量\%配合 PTFE, 厚さ 0.3 $\mathrm{mm}$ )

\section{c. 潤滑剂}

信越シリコーン KF 965 (10000 cs)

d. プレス

延伸用高圧プレス：プレスカが 1000 トンと 2500 ト ンのプレス

予備加熱用低圧プレス：プレスカが 100 トンのプレ ス

\section{2 プレス延伸法}

すでに報告した各種プレス延伸法の中の金型温度一 定法を用いた。金型温度一定法を図 1 に示した。図 1 に おいて, 装置は球面状表面金型を有する予備加熱用低 圧プレスと平面状表面金型を有するプレス延伸用高圧 プレスの 2 台からなる.プレス延伸用金型表面に潤滑

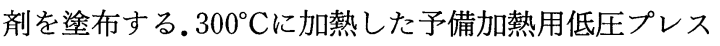
で Preformを $300^{\circ} \mathrm{C}$ 球面状に予熱し, 次いで一定温 度 $\left(80^{\circ} \mathrm{C}\right.$ るいは $\left.240^{\circ} \mathrm{C}\right)$ に加熱した延伸用高圧プレス 金型で球面状予熱 Preform をプレス延伸する.

Preform は図 2 に示すように，4〜40 枚の Preform を積層し, 各 Preform の界面にはガラス繊維配合 PTFEフィルムを挟み, さらに全体を $0.15 \mathrm{~mm}$ 厚の

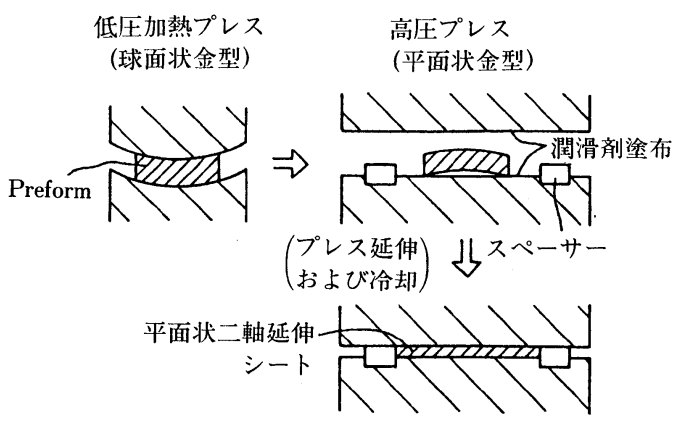

図 1 金型温度一定法によるプレス延伸 


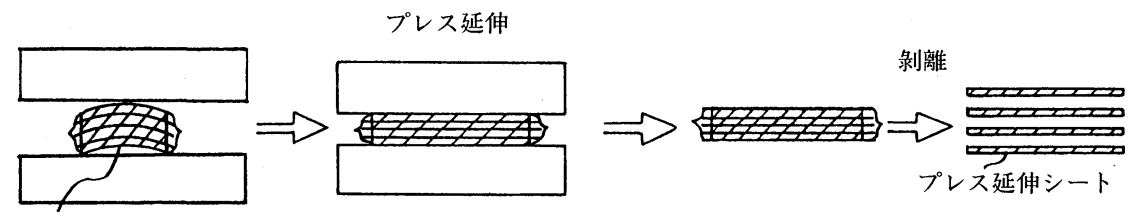

積層 Preform

図 2 積層 Preform のプレス延伸

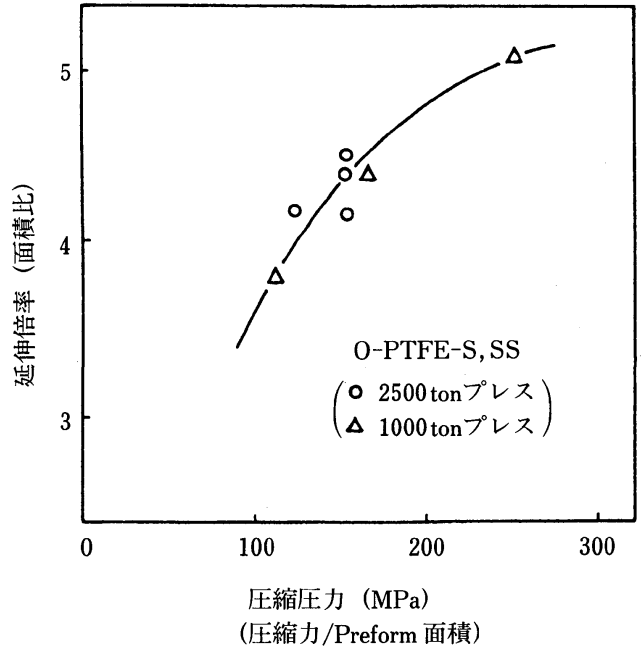

図 3 圧縮圧力-延伸倍率曲線

PTFE フィルムで真空包装し, 合計厚みを $30 \sim 40 \mathrm{~mm}$ の厚肉 Preform とした. PTFE は非接着性であり, 積 層された PTFE は延伸時に相互に密着しない. 逆に相 互に滑りやすく，この滑りをなくすために各 Preform の界面にガラス繊維配合 PTFE フィルムを介在させ, この PTFE フィルムの表面の微細な凹凸が Preform 相互の滑りを止め, プレス延伸時の積層を安定に保っ た.

真空包装は積層 Preform の間に空気がトラップさ れるのを排除して延伸シートの外観を良好にすること と, 潤滑剤を延伸シートに付着させないためである. PTFE は十分に潤滑性が良く, 潤滑樹脂フィルムの働 きもした。

予備加熱用低圧プレスで $10 \mathrm{MPa}$ の圧力で Preform を予熱し，プレス延伸用高圧プレスで高圧力で圧縮延 伸した。延伸倍率と必要圧縮圧力の関係を測定して図 3 に示した。

プレス延伸金型の温度は, $80^{\circ} \mathrm{C}$ と $240^{\circ} \mathrm{C}$ の 2 種類で プレス延伸した。金型の温度と延伸倍率の組み合わせ を表 1 に示す 4 種のダレード，すなわち O-PTFE-S， O-PTFE-SS, O-PTFE-H, O-PTFE-HH とした. プレス延伸金型内で延伸して約 10 分間圧縮を続け,冷 却したPTFE を金型外に取り出した。金型外に取り出
表 1 二軸延伸 PTFE シートのグレード

\begin{tabular}{|c|c|c|c|c|}
\hline \multirow[b]{2}{*}{ グレード } & \multicolumn{2}{|c|}{ 延伸シート } & \multicolumn{2}{|r|}{ プレス延伸条件 } \\
\hline & $\begin{array}{l}\text { 延伸倍率 } \\
\text { (面積比) }\end{array}$ & 耐熱性 & 金型温度 & $\begin{array}{l}\text { プレス直後の金型内で } \\
\text { の廷伸倍率(面積比) *1 }\end{array}$ \\
\hline O-PTFE-S & 3.5倍 & \multirow{2}{*}{$\begin{array}{l}80^{\circ} \mathrm{C} \text { 以上で } \\
\text { 収縮を起こす }\end{array}$} & \multirow[t]{2}{*}{$80^{\circ} \mathrm{C}$} & 3.7倍 \\
\hline O-PTFE-SS & 4.5倍 & & & 4.5倍 \\
\hline O-PTFE-H & 3.5 倍 & \multirow{2}{*}{$\begin{array}{l}200^{\circ} \mathrm{C} \text { 以上で } \\
\text { 収縮を起こす }\end{array}$} & \multirow[t]{2}{*}{$240^{\circ} \mathrm{C}$} & 6 倍 \\
\hline O-PTFE-HH & 4.2倍 & & & 8 倍 \\
\hline
\end{tabular}

した延伸シートは一部分収縮を起こし，表 1 に示す各 延伸倍率のシートを得た。

\section{3． 実験結果および考察}

\section{1 二軸延伸 PTFE シートの一般物性}

4 種のプレス延伸 PTFE シートの一般物性を未延 伸 PTFE と対比して表 2 に示した.PTFE と GF は比 重がほほ同一である.プレス延伸 PTFE シートは比重 が 2.1 の高密度である. O-PTFE-H と O-PTFE-HH は耐熱性に優れ, $200^{\circ} \mathrm{C}$ まで収縮を起こさず, O-PTFE$\mathrm{S}$ と O-PTFE-SS は $80^{\circ} \mathrm{C}$ 越えると収縮を起こす。プ レス延伸 PTFE シートは引張破断強さ, 耐圧縮クリー プ性，アイゾット衝撃強さに優れている．次に個々の 性能について述べる.

\section{2 耐圧縮性}

O-PTFE-S または O-PTFE-SS の延伸条件で延伸 倍率を変えて成形し, $200^{\circ} \mathrm{C}, 50 \mathrm{MPa}, 1$ 時間の圧縮ク リープ量と延伸倍率の関係を測定して図 4 に示した。 延伸倍率が大きいほどクリープ量は減少し，耐圧縮ク リープ性は向上した。

図 5 にプレス延伸 PTFE シートの圧縮圧力と圧縮 永久歪みの関係を示した。延伸倍率の大きい $\mathrm{O}^{-}$ PTFE-SS の圧縮永久歪みは極めて小さく，耐圧縮性 に優れていた。

図 6 にプレス延伸 PTFE シートの圧縮回復曲線を 示した.

プレス延伸 PTFE シートをガスケット状に削り出 して, シール材としての性能を評価する室温シール試 
表 2 プレス延伸 PTFE シートの各種性質

\begin{tabular}{|c|c|c|c|c|c|c|c|c|c|c|}
\hline \multirow{2}{*}{ 性 } & \multirow{2}{*}{ 質 } & \multirow{2}{*}{\multicolumn{2}{|c|}{ 試験方法 }} & \multirow{2}{*}{ 単位 } & \multicolumn{4}{|c|}{ O-PTFE } & \multicolumn{2}{|c|}{ 末延伸 PTFE } \\
\hline & & & & & $\mathrm{S}$ & SS & $\mathrm{H}$ & $\mathrm{HH}$ & PTFE (Pure) $* 1$ & PTFE (GF 配合)*2 \\
\hline 比 & 重 & \multicolumn{2}{|c|}{ ASTM D792 } & - & 2.1 & 2.1 & 2.1 & 2.1 & 2.1 & 2.1 \\
\hline 硬 & 度 & \multicolumn{2}{|c|}{ Durometer } & Shore & D56 & D56 & D56 & D56 & D56 & D56 \\
\hline \multicolumn{2}{|c|}{ 引張破断強度 } & \multicolumn{2}{|c|}{ JIS K6888 } & $\mathrm{MPa}$ & 51 & 57 & 51 & 56 & 32 & 19 \\
\hline 引張砛 & 伸度 & \multicolumn{2}{|c|}{ JIS K6888 } & $\%$ & 220 & 170 & 220 & 180 & 340 & 360 \\
\hline \multirow{3}{*}{\multicolumn{2}{|c|}{$\begin{array}{c}\text { 圧縮永久丕み } \\
\text { (圧縮クリープ) }\end{array}$}} & \multicolumn{2}{|c|}{$200^{\circ} \mathrm{C}, 13 \mathrm{MPa}, 100 \mathrm{~h}$} & $\%$ & 7 & 5 & 16 & 12 & 47 & 24 \\
\hline & & \multicolumn{2}{|c|}{$200^{\circ} \mathrm{C}, 21 \mathrm{MPa}, \quad 1 \mathrm{~h}$} & $\%$ & 9 & 6 & 20 & 14 & 51 & 18 \\
\hline & & \multicolumn{2}{|c|}{$200^{\circ} \mathrm{C}, 50 \mathrm{MPa}, \quad 1 \mathrm{~h}$} & $\%$ & 28 & 15 & 32 & 18 & 70 & 40 \\
\hline \multirow{2}{*}{\multicolumn{2}{|c|}{$\begin{array}{l}\text { アイゾット衝撃 } \\
\text { 強度(ノッチ付き) }\end{array}$}} & \multirow{2}{*}{ ASTM D256 } & $23^{\circ} \mathrm{C}$ & $\mathrm{kg} / \mathrm{cm} \cdot \mathrm{cm}$ & 20 & 25 & 30 & 34 & 12 & - \\
\hline & & & $-196^{\circ} \mathrm{C}$ & $\mathrm{kg} / \mathrm{cm} \cdot \mathrm{cm}$ & 12 & 14 & 19 & 20 & 6 & - \\
\hline \multirow{2}{*}{\multicolumn{2}{|c|}{ 熱 収 縮 }} & \multicolumn{2}{|c|}{$30^{\circ} \mathrm{C}, 20 \mathrm{~h}$} & $\%$ & 0.5 & 0.5 & 0 & 0 & 0 & 0 \\
\hline & & \multicolumn{2}{|c|}{$200^{\circ} \mathrm{C}, 10 \mathrm{~h}$} & $\%$ & 9 & 12 & 0 & 0 & 0 & 0 \\
\hline
\end{tabular}

$* 1$ : 日本バルカー工業(㑣)，\#7000，*2：日本バルカー工業(㑣，\#7020

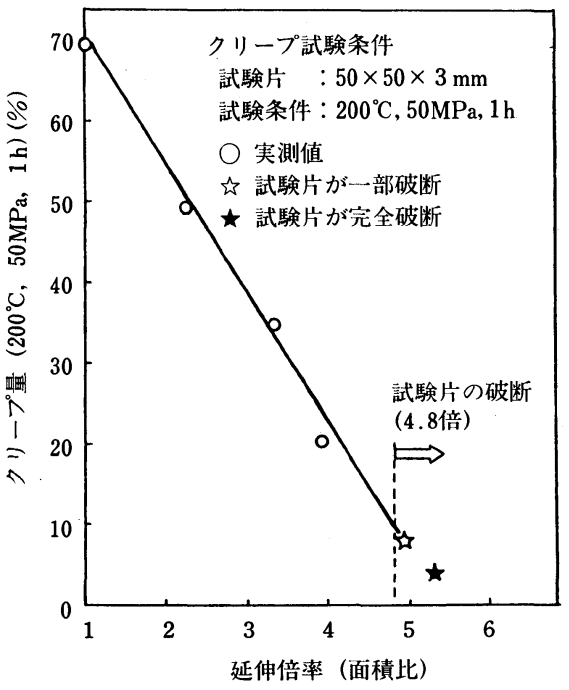

図 4 延伸倍率とクリープ量の関係

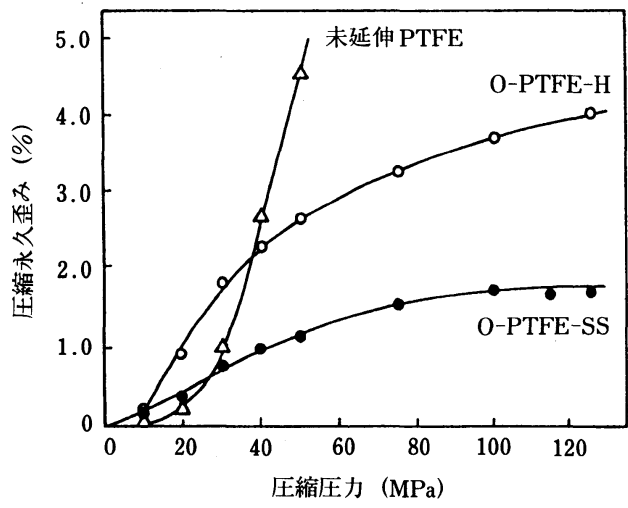

試 験 片: $100 \mathrm{~mm} \times 100 \mathrm{~mm} \times 2 \mathrm{mmt}$ 試験方法：鏡面板の間に試験片を置き，圧縮力 を 1 時間負荷した後圧縮力を除き， 压縮永久歪みを測定する。

図 5 圧縮圧力と圧縮永久歪みの関係
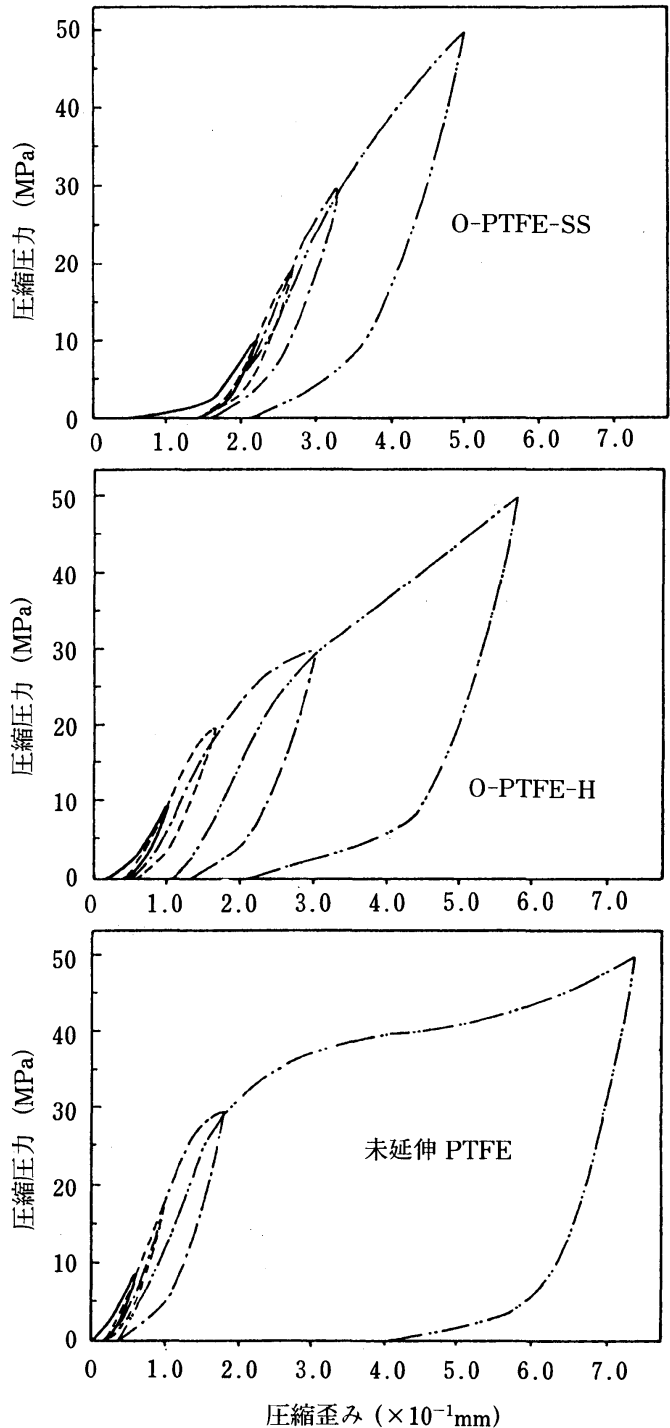

図 6 圧縮回復試験 

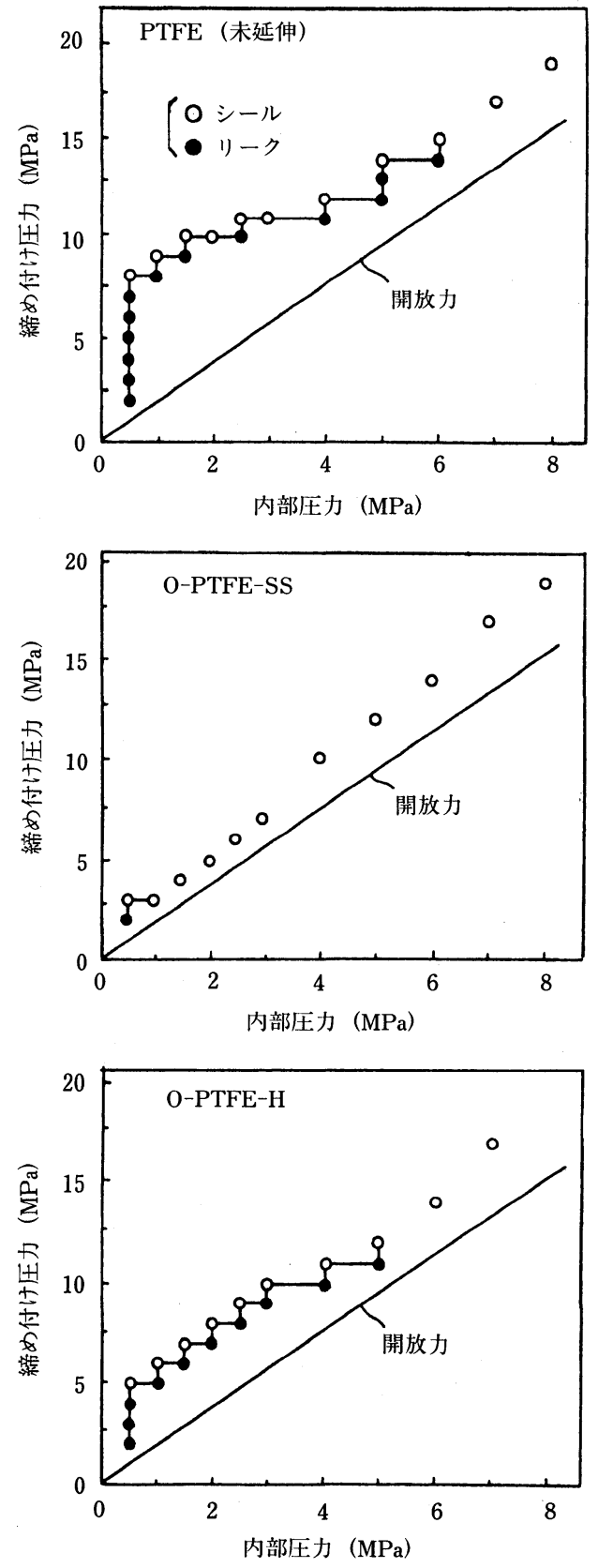

図 7 室温シール試験

験の結果を図 7 に示した。試験法はガスケット状の試 料を容器のフランジに装着し, 容器の各窒素内圧段階 でフランジを締め付け, 漏れ開始圧力を求める方法で ある. 内圧負荷時間は 15 分である. プレス延伸 PTFE シートは無延伸 PTFE シートに比較して優れたシー ル特性を示した。特に O-PTFE-SS は優れたシール性 を示した.PTFE は耐化学薬品性に優れているため, 化学薬品などの容器, 反応器, パイプなどのシール材

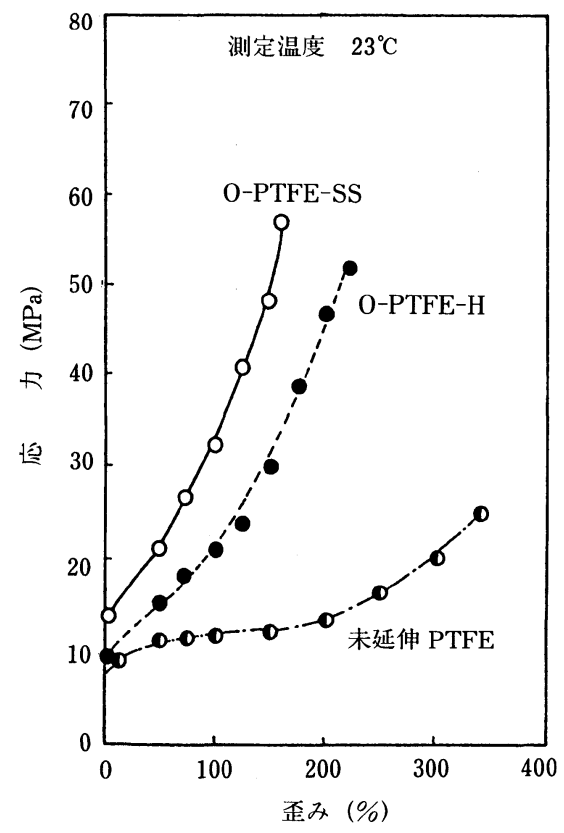

図 8 引張応力-歪み曲線

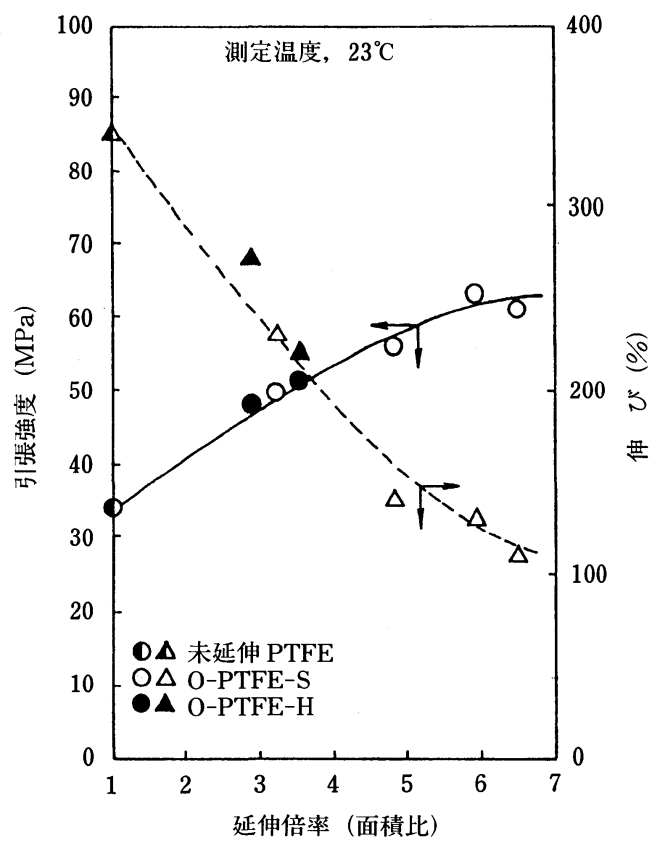

図 9 延伸倍率と引張強度, 伸びの関係

に多く使用されているが, 無延伸 PTFE はクリープし やすいために従来頻繁に増し締めを必要としてきた。 プレス延伸 PTFE シートは耐クリープ性に優れ,ガス ケットなどのシール材に好適である。特に O-PTFE$\mathrm{SS}$ あるいは O-PTFE-S は $80^{\circ} \mathrm{C}$ 越えると収縮して 厚肉になろうとするため, $80^{\circ} \mathrm{C}$ 以上ではセルフシーリ 
ング機能を有している.

\section{3 引張特性}

図 8 はプレス延伸 PTFE シートの引張試験時の応 力-歪み曲線を示す。

図 9 はプレス延伸 PTFE シートの延伸倍率と引張 強度, 引張伸びの関係を示す. 延伸により弾性率が増 大し，破断伸度は低下した。

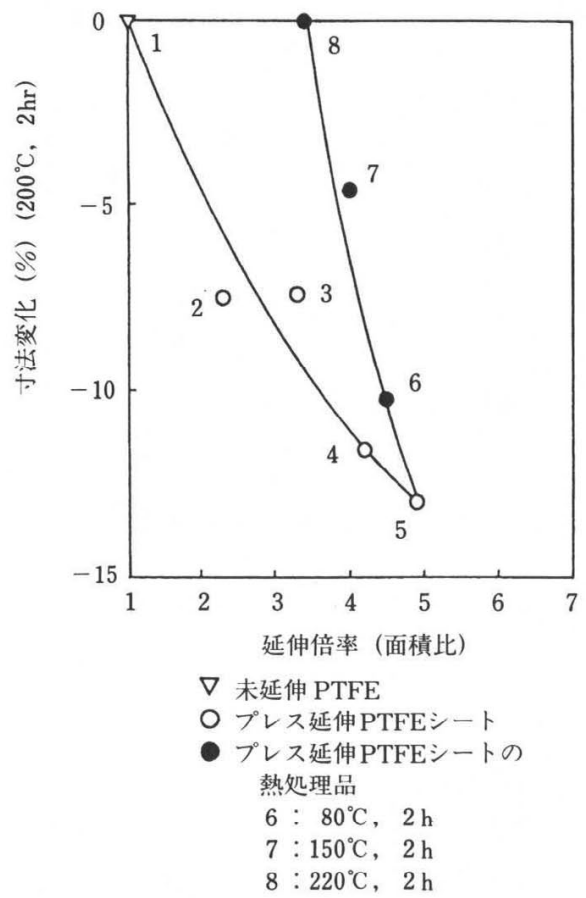

図 10 加熱による寸法变化（熱処理の有無）

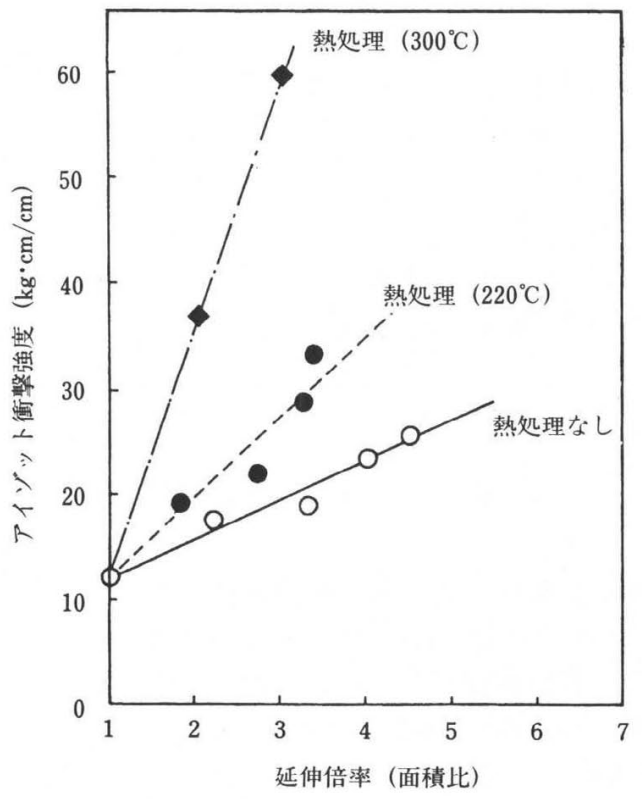

図 11 アイソット衝撃強度

\section{4 熱処理の効果}

図 10 に各シートを $200^{\circ} \mathrm{C}, 2$ 時間加熱したときの寸 法変化を示した。すなわち, S-Gradeのプレス延伸条 件で延伸した各延伸倍率の延伸シートの寸法変化と, S-Grade の 5 倍延伸シートを熱処理した後のシート の寸法変化を示した. プレス延伸 PTFE シートは熱処 理により大幅な性能の変化が見られた。

図 11 は，熱処理有りと熱処理無しの S-Grade のア イゾット衝撃強度と延伸倍率の関係を示した。熱処理 により衝撃強度は大幅に増大した。

\section{5 走査電子顕微鏡観察}

図 12 に冷却時破断面の走查電子顕微鏡写真を示し た. Speerschneider はPTFE の構造について報告し ている ${ }^{8}$. すなわち, フリーベーキング PTFE(無延伸 PTFE) は図 13 に示すように0.1 1 $\mu \mathrm{m}$ の幅を有す る長い带（Band）とその帯に直角の方向に並んだ縞 (Striation)からなり, PTFE 分子は縞に平行に配列し た特異なミクロ構造を有する。これを一軸に延伸する と, 図 14 に示すような変形が起こり, 主に非晶部で変 形していると報告している. プレス延伸 PTFE シート の電子顕微鏡観察の結果, プレス延伸シートは図 12 に 示すように Band 構造が完全になくなっている.プレ ス延伸後も結晶化度の変化はなかった。プレス延伸 シートを融点以上に加熱すると元の Band 構造に戻る が, 融点以下で加熱すると収縮が起こり配向は戻るが Band 構造には戻らなかった. プレス延伸により非晶 部の変形が極端に起こり, 結晶 Platelet がばらばらに なったと推定される.
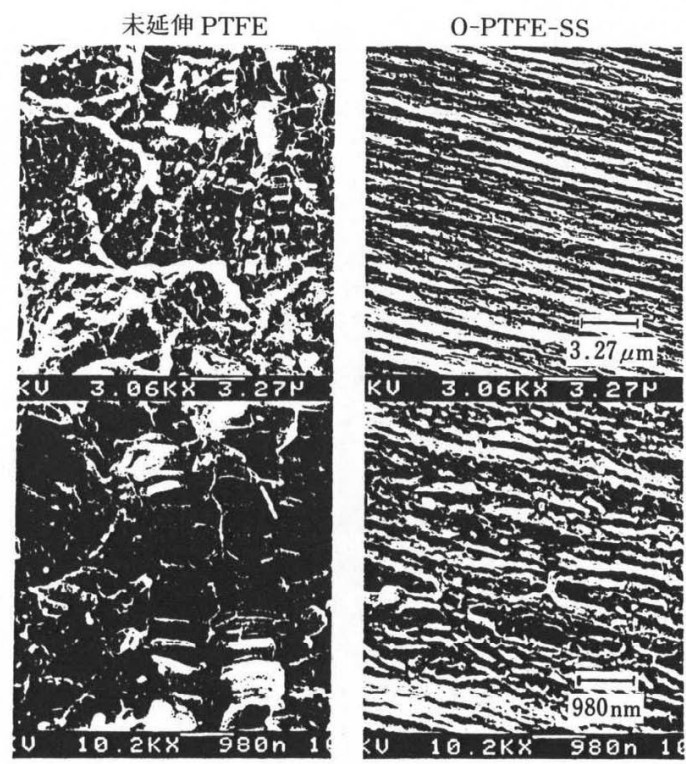

図 12 破断面の走查電子顕微鏡観察 


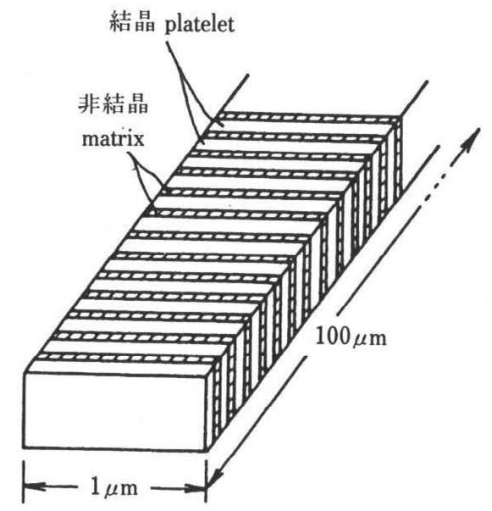

図 13 フリーベーキング PTFE のミクロ構造

未延伸 PTFE
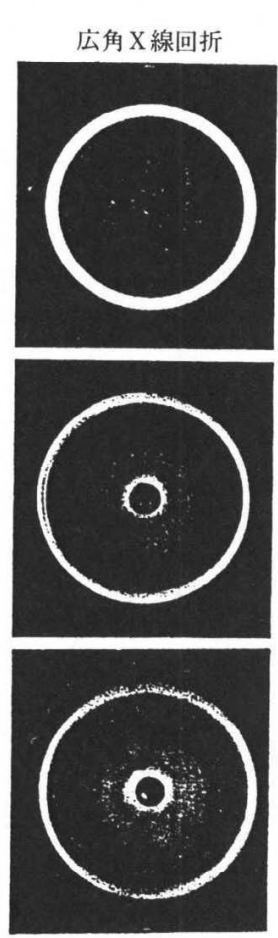

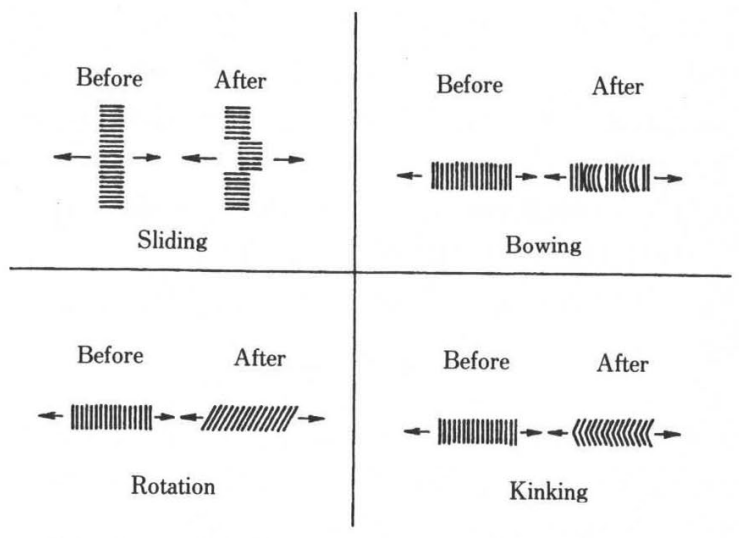

図 14 一軸延伸による PTFE 分子鎖配列の変化 O-PTFE-SS

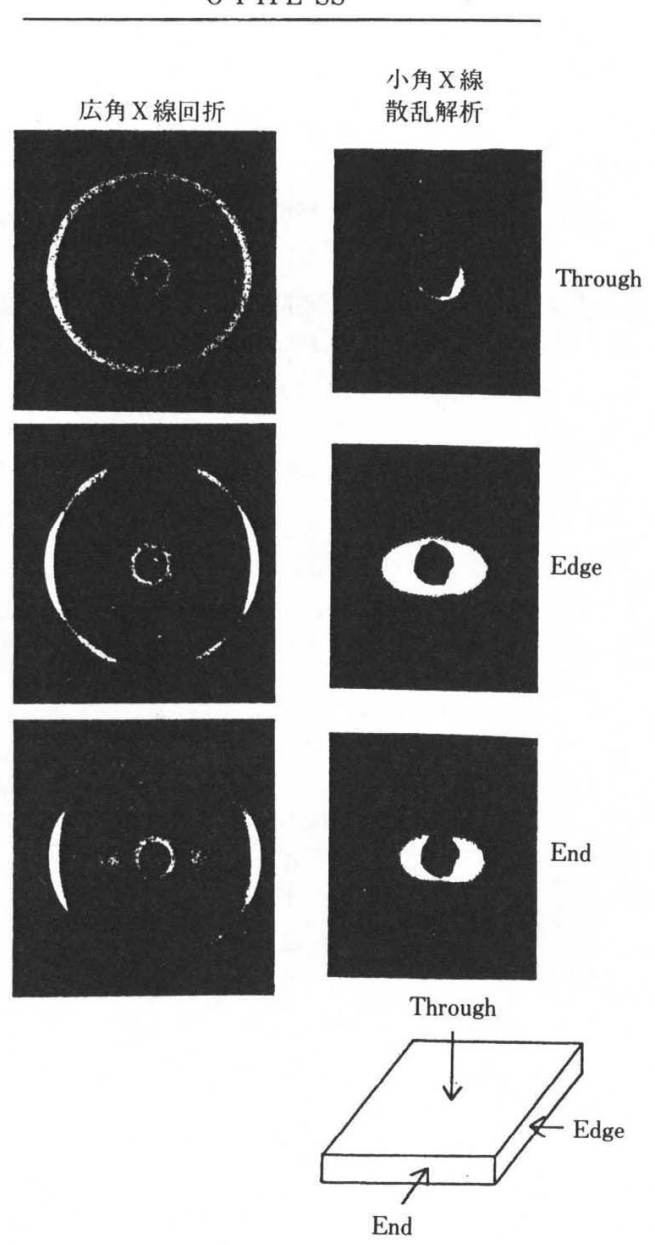

図 $15 \mathrm{X}$ 線による観察

\section{6 広角 $\mathrm{X}$ 線回折および小角 $\mathrm{X}$ 線散乱解析}

プレス延伸 PTFE シートの広角 X 線回折と小角 X 線散乱解析の写真を図 15 に示した。延伸シートは図 15 の End 方向と Edge 方向で形成される面に二軸延
伸されている.

Through 方向の広角 $\mathrm{X}$ 線回折から，プレス延伸 PTFE は分子鎖がシート面内で無秩序に存在してお り, 極めて異方性の少ない状態となっている。一方, 
Edge 方向および End 方向の広角 X 線回折から, 分子 鎖がシート表面に対して平行な方向に強く配向してい る.また配向軸に対して +60 度およびー 60 度傾いた方 向にも弱く配向している.

小角 X 線散乱解析より, シートの Through 方向で はボイドは観察されないが, Edge 方向および End 方 向では面方向に配向したボイドの存在が観察される.

\section{4. 結論}

超高分子量 PTFE をプレス延伸法で二軸延伸し, 比 重が 2.1 の緻密な二軸延伸シートを得た。この二軸延 伸シートは,

(1) プレス延伸により弾性率が増大し, 伸度は低下 した。

(2) 圧縮永久歪みが極めて小さく，耐圧縮力に優れ る.

(3) ガスケット状にしたシール試験の結果は, 優れ たシール特性を示した。

(4) 熱処理により,アイゾット衝撃強度は著しく増 大した。

(5) 電子顕微鏡観察では, プレス延伸により PTFE 特有のバンド構造は消失していた. 延伸後も結晶 化度は変化なく, プレス延伸により非晶部の変形 が極端に起こり, 結晶 Platelet がバラバラになっ
たと推定される。

5. おわりに

シール試験の結果については, 日本バルカー工業 (株), シール研究所での測定結果を引用させていただ いた．本報告の開発には多くの人が係わったが，代表 して 4 人が報告した.

\section{参 考 文 献}

1) 羽田次夫, 高橋重三, 野村春治, 黒川正隆：高分 子論文集, 40 (8)，467（1983）

2) Hashida, S., Hirakawa, S. and Namio, H. $: J$. Applied Polymer Sci., 32, 5685 (1986)

3) W. L. Gore \& Associates Inc. : 特公昭 5118991

4）奥山裕司, 金元哲夫：Polymer Preprints, Japan, 41 (11) , 4502 (1992)

5) Okuyama, H., Kanamoto, T. and Porter, R. S. : J. Mater. Sci., 29 (24), 6485 (1994)

6) Okuyama, H., Kanamoto, T. and Porter, R. S. : ANTEC'95, 1809 (1995)

7) 片岡 紘, 豊内 薰: 成形加工, 9 (4), 306 (1997)

8) Speerschneider, C. J.: J. Applied Physics, 33 (5) , 1871 (1962) 